\title{
When climate change is not blamed: the politics of disaster attribution in international perspective
}

\author{
Myanna Lahsen $^{1,2}$ (D) Gabriela de Azevedo Couto ${ }^{2} \cdot$ Irene Lorenzoni $^{3}$
}

Received: 18 September 2019 / Accepted: 17 December 2019 / Published online: 27 December 2019

(C) The Author(s) 2019

\begin{abstract}
Analyzing the politics and policy implications in Brazil of attributing extreme weather events to climate change, we argue for greater place-based sensitivity in recommendations for how to frame extreme weather events relative to climate change. Identifying geographical limits of current recommendations to emphasize the climate role in such events, we explore Brazilian framings of the two tragic national disasters, as apparent in newspaper coverage of climate change. We find that a variety of contextual factors compel environmental leaders and scientists in Brazil to avoid and discourage highlighting the role of climate change in national extreme events. Against analysts' general deficit-finding assumptions, we argue that the Brazilian framing tendency reflects sound strategic, socio-environmental reasoning, and discuss circumstances in which attributing such events to climate change - and, by extension, attribution science - can be ineffective for policy action on climate change and other socio-environmental issues in need of public pressure and preventive action. The case study has implications beyond Brazil by begging greater attention to policies and politics in particular places before assuming that attribution science and discursive emphasis on the climate role in extreme events are the most strategic means of achieving climate mitigation and disaster preparedness. Factors at play in Brazil might also structure extreme events attribution politics in other countries, not least some other countries of the global South.
\end{abstract}

Keywords climate change · disasters · extreme events · attribution politics · global South · Brazil · United States $\cdot$ framing

\footnotetext{
Highlights

The policy value of attributing extreme weather events to climate change varies depending on national circumstances and competing policy concerns.

Higher levels of climate skepticism - a phenomenon most prevalent in a subset of countries in the global North-enhance the value of attributing extreme weather events to climate change.

Blame politics in Brazil discourage attribution of extreme weather events to climate change.

Counter-intuitively, vulnerability reduction can sometimes be best served by disassociating extreme events from climate change.
}

\section{Myanna Lahsen}

myannal@gmail.com

Extended author information available on the last page of the article 


\section{Introduction}

Extreme events can focus attention on climate change and challenge skepticism about its reality and whether it will have deleterious consequences, key foci of climate skepticism (Rahmstorf 2004). For example, US media often call attention to the possible role of climate change in devastating events such as the 2017 US hurricanes Harvey and Irma. Instances of weak or absent attributions of extreme events to climate change in the US media and beyond are negatively evaluated by analysts, referred to as failures, missed opportunities, and a function of insufficient understanding or journalistic capacity (Barkemeyer et al. 2017; Boykoff 2011; Shanahan 2009; Mann et al. 2017). Concurrently, US-based thought leaders take the message to international arenas. Writing in Science recently, Marcia McNutt-the journal's former editor-in-chief, a geophysicist, and current president of the US National Academy of Science - expressed the pervasive but often implicit hope associated with attribution science: "Whether the extreme event is a heatwave, flood, drought, wildfire, or hurricane, demonstrating to the public how climate change is amplifying the negative impacts of these events can spur more immediate action" (Mcnutt 2019, p. 411). The same premise structures the advice of communication strategists associated with organizations such as the World Meteorological Organization (WMO) and the Aspen Institute for Global Change, whose Climate Communication Project is advised by a long list of highly distinguished American climate experts from the natural and social sciences and the humanities (see https://www. climatecommunication.org/who-we-are/about-us/). Evoking examples from around the world, they criticize media for "far too often" failing to seize on the "clear opportunity" to highlight the climate role in extreme events where scientists are confident that it has played a role, and call on experts to emphasize the links in their communications (Hassol et al. 2016).

The basis for this premise and the geographical limits to its applicability are underexplored. Attributing extreme events to climate change "can" spur action, McNutt (2019) writes. But when and where is that the case? Is it universally the case and, if not, in what circumstances is such linking likely to prompt the desired action, and when is it not? Little empirical research illuminates these questions, the answers to which can inform how science is effectively focused and communicated in different contexts, and given weight relative to other pressing problems.

We explore these questions through the case of Brazil, which suffers great human and material losses from droughts and weather-related floods and landslides. From 1990 to 2010, extreme events caused financial, physical, and psychological damages for an estimated 90 million people, leaving thousands of people dead and 7.5 million homeless (Bandeira et al. 2016). ${ }^{1}$ We examine whether and how Brazil's leading newspaper, Folha de São Paulo, linked two particularly tragic national extreme events in the Southern State Santa Catarina in 2008 and in the Serrana highlands of the state of Rio de Janeiro in 2011. Caused by flooding and landslides from heavy rainfalls, the two events affected nearly two million persons, causing a thousand human deaths and an estimated USD4.5 billion in material damages (Banco Mundial 2012a, 2012b).

Scientific capacity to attribute individual extreme events to climate change has improved, but much uncertainty remains. The climate role is especially uncertain for droughts, extreme rainfall, and storms (Stott et al., 2016), also in Brazil (Martins et al. 2018). Moreover, even the

\footnotetext{
${ }^{1}$ For indicators of Brazil's climate vulnerability relative to other countries, see http://daraint.org/climatevulnerability-monitor/climate-vulnerability-monitor-2012/ (accessed 3 June 2018).
} 
soundest of scientific facts are inflected with diversity of meanings and morality as they travel through complex channels of mass communications and socio-cultural and political systems (Callison 2010; Jasanoff 2004). Interpretations that get social and political traction are not necessarily the ones that are most scientifically robust, and scientific uncertainty enhances the space for divergences in interpretations.

Rather than seeking to establish the most scientifically robust interpretations, we are interested in how persons interpret and choose to discursively present (i.e., "frame") the causes of the two extreme events in focus, specifically whether or not actors choose to attribute extreme events to anthropogenic climate change. Because of the shaping effects of policy opportunities, and broader power-inflected discursive contexts on framing choices (Snow 2008), we also identify the most frequent ("major") topics of debate and dominant policy positions apparent in the climate coverage of three major elite Brazilian newspapers during the two periods in focus (2007-2008 and 2011).

Our findings challenge the one-frame-fits-all assumption about how disasters should be framed to achieve desired action on climate and, even, that climate change always should be the emphasized cause. Showing how contextual factors can reduce the policy value of attribution science in some national contexts, the findings beg awareness and revision of place-based - perhaps US-centric - assumptions underpinning current global recommendations for improved communication practices about extreme events. As such, they also beg recognition of the importance of understanding the politics of extreme events attribution in specific locations before assuming that establishing the role of climate change in them will stimulate action, and issuing global recommendations on that premise. While we focus on Brazil, we discuss factors at play in Brazil which likely also influence attribution politics in some other countries, especially in the global South.

\section{Methods}

We selected climate change-mentioning articles in three major daily elite Brazilian newspapers, found using common terms for climate change in Portuguese (mudança climática, mudanças climáticas, aquecimento global, corresponding to climate change, climate changes, and global warming in English) in the Factiva database (henceforth, "climate changementioning articles"). We chose Folha de São Paulo, Estado de São Paulo, and Valor Econômico given their national prominence and their accessibility via the Factiva database, ${ }^{2}$ focusing our more detailed content analyses of the two disasters on Folha de São Paulo, Brazil's single most circulated newspaper during the periods in focus. The three newspapers do not span a diverse political spectrum, as Brazil's newspapers lack significant political diversity, and their relatively minor differences across the political spectrum do not translate into significant differences in climate coverage (Painter and Ashe 2012).

\footnotetext{
${ }^{2}$ The four top daily print newspapers in the country are Folha de São Paulo (560,000), O Globo (350,000), O Dia (250,000), and $O$ Estado de São Paulo (242,000) (source: http://www.pressreference.com/Be-Co/Brazil. $\mathrm{html}$, accessed 27 November 2019). Valor Econômico $(58,000)$ is the largest national financial newspaper and ranks fifth. Digital signatures are increasing rapidly (Pasquali 2019). Counting non-paying digital readers, the readerships soar to millions - approximately 20 million, in the case of Folha de São Paulo, for example (https://knightcenter.utexas.edu/blog/00-17765-brazilian-newspapers-have-broken-audience-records-and-digitalsubscriptions-have-incre).
} 


\subsection{Identification and analysis of discursive linking of extreme events to climate change}

To identify relevant discussions and allow close analysis of how Brazilians framed the two extreme events, we narrowed our focus to the climate change-mentioning articles in a single, leading newspaper. Selecting Folha de São Paulo and a 12-month period following each disaster's onset yielded 821 and 280 articles, respectively, summing 1101. Searching these articles for the keywords "Santa Catarina" and "Serrana" yielded merely 18 articles. We subsequently analyzed framing patterns (henceforth referred to as "Discursive Linking Analysis"), retaining only articles in which the extreme events were linked, delinked, or otherwise discussed in the context of climate change. This sift reduced the number of relevant articles to 13. Results from this analysis are discussed in Sections 3.1 and 3.2.

\subsection{Identification and analysis of major debates}

Our Major Debate Analysis examined all climate change-mentioning articles in the three newspapers during 2007-2008. For 2011, we examined only articles in Folha de São Paulo and Estado de São Paulo, as the Factiva database discontinued access to Valor Econômico after 2009. This yielded 4111 articles for the 3 years (3550 articles in 2007-2008 and 561 articles in 2011). ${ }^{3}$

To identify debate statements in this corpus, we applied a verb-centered approach, searching for Portuguese words commonly used when citing individuals and/or organizations. In Portuguese, we used the term "according to" ("segundo") and the verbs "inform," "say," "tell," "confirm," and "assert," including conjugations of these verbs commonly used when citing persons (informar, dizer, falar, afirmar, including "informa," informou," "disse," "diz," "afirmou," and "affirma"), testing and establishing the reliability of this method. ${ }^{4}$ We found debate statements in 527 articles (498 in 2007-2008 and 92 in 2011, corresponding to 14\% and $16.4 \%$ of the climate change-mentioning articles during the respective periods). Using the Discourse Network Analyzer (DNA) software, ${ }^{5}$ we coded all climate relevant statements in the 527 articles to capture the belief or policy position expressed and the individual(s) and/or organization(s) who expressed it. We subsequently deductively grouped each statement under the umbrella of a single representative statement to reduce heterogeneity. Examining the contents of the statements included under each wider ranging statement, we identified the topics which specific actors most raised, the number of times they were featured doing so, and their positions for or against the various umbrella debate statements. To limit the focus to

\footnotetext{
${ }^{3}$ The years 2007-2008 were selected because they were the focus of an international comparative analysis under the COMPON project, of which this study is a part. As such, it provides information about the general context of the Serrana disaster, which occurred in November 2008. Led by Lahsen, the Brazilian team under COMPON added analysis of major debates in 2011, to update the major analysis. The Serrana disaster occurred 11 January 2011, wherefore the 2011 climate change-mentioning articles cover its onset and most of the year following its onset.

${ }^{4}$ To test the validity of our verb-centered approach to statement identification, we applied an alternative search limited to three prominent actors. After searching the 3550 articles from 2007 to 2008 for the full names and abbreviations for the ministries of the Environment (MMA), Foreign Relations (MRE), and Science and Technology (MCT), we compared the results from the two search methods, finding close (98\%) equivalence: the alternative approach yielded 95 articles containing debate statements by these three actors, only two of which lacked any of our chosen verbs.

${ }^{5}$ https://www.philipleifeld.com/software/software.html.
} 
dominant patterns, we specifically examined statements that were expressed by actors ten or more times. Key, relevant results from this analysis are presented in Section 3.3.

\section{Findings: conspicuous delinking of extreme events from climate change}

Our Discursive Linking Analysis exploring coverage of the two prominent national disasters in Folha de São Paulo revealed a marked deemphasis on the role of climate change.

\subsection{Santa Catarina 2008}

Caused by heavy rain on 20-24 of November, the 2008 flooding in Santa Catarina affected approximately 60 municipalities and more than 1.5 million people. Especially hard-hit areas measured a total cumulative rainfall of $1000 \mathrm{~mm}\left(1000 \mathrm{l} / \mathrm{m}^{2}\right)$ in November, over six times the normal average (Banco Mundial 2012a). A total of 110 persons died, and scores more went missing. A total of 78,000 people were forced to leave their homes. In total, 38,000 rural properties were affected, of which some 6000 were destroyed along with approximately 350 health units and public schools. Losses were estimated at roughly USD 2.5 billion.

Of a total of 821 climate change-mentioning articles during the 12 months following the onset of the disaster on 24 November 2008, only nine implicitly or explicitly related the disaster to climate change. Written by a former President of Brazil, one of them framed the extreme event as nature's revenge in response to human assaults upon it, but in vague terms and without ascribing responsibility or blame to anyone or anything in particular (Sarney 2008). The remaining eight articles exhibited markedly similar framings. Four were by national environmental leaders - two politicians and an NGO leader. The other four were authored by journalists. To varying extents, these articles acknowledged that extreme events are projected to be intensifying with climate change, but none of them specifically related the Santa Catarina disaster to climate change. In quite an emphatic and detailed manner - even in an article with a headline calling attention to climate change ("Climatic chaos tends to worsen in the future" (Angelo 2009)) - all eight articles stressed that this extreme event could not be unequivocally attributed to climate change, pointing instead to the lack of adequate measures to reduce vulnerability to their impacts (Angelo 2009; Barros 2008; Gabeira 2008a, 2008b; Geraque 2008; Silva 2008; Smeraldi 2008; Veríssimo 2008). Roberto Smeraldi, the former director of a Brazilian environmental NGO, described local deforestation, some of it illegal, as the principal cause:

But the extreme nature of the climate phenomenon that affected Santa Catarina is not enough to explain the size of the impacts. There is also the unprecedented vulnerability of our territory in the face of an exacerbated climate. [...] The extreme vulnerability of the territory of Santa Catarina - and other important regions of the country - is mainly due to local deforestation, with significant changes in land use and water management. If the Forest Code had been respected, especially with regard to permanent preservation areas, which include hilltops, hillsides and riparian forests, we would not see erosion and silting on this scale. (Smeraldi 2008) (translated from Portuguese by the first author, emphasis added) 
Smeraldi called attention to the poor enforcement of laws prohibiting human dwellings in the permanent preservation areas, and to the social injustice that leaves poor people disproportionately vulnerable because economic necessities drive them to live in precarious places prone to landslides and flooding. He deplored political pressures from the agricultural lobby and politicians to weaken forest protection laws - pressures which eventually succeeded, resulted in the 2012 revised Forest Code.

Environment Minister until earlier that year, Senator Marina Silva's article (Silva 2008) similarly attacked the agricultural lobby in both business and government for pressuring to weaken forest protection. Referring to the Santa Catarina disaster, she makes the point that these will adversely affect disaster prevention and contradict national commitments under the climate convention.

Rio de Janeiro's former Green Party politician and national television host, Fernando Gabeira suggested that the traditional seasonal rains, of which the Santa Catarina event was an expression, could be seized upon as an opportunity to place the topic of climate mitigation and adaptation on the public agenda "before the next disaster" (Gabeira 2008a). His optimism was tempered by his acknowledgement that efforts at improving climate adaptation and mitigation "... in truth, will prove difficult, because a majority [unspecified, but presumably lobby groups and aligned decision makers, to whom Smeraldi also referred above] consider talk about prevention boring enviro-babble ["ecochatice"]" (Gabeira 2008a). In a second article, Gabeira (2008b) similarly questioned the effectiveness of calling attention to climate change as a cause of the event. Noting Santa Catarina's long tradition of extreme eventinduced disasters independent of climate change, he questioned whether "the best strategy in Brazil is to call attention to climate change" rather than "basic things that could unite us: unclogging drains, relocating people living in dangerous slopes or illegally near the waterline." Like Smeraldi, Gabeira criticized local policy-makers for the absence of disaster prevention (Gabeira 2008a), a common feature in framings around these two disasters.

Echoing the other comments above, an article by a Folha de São Paulo editor interpreted local government officials' attributions of the disaster to climate change as convenient means to escape blame. In the article entitled "Rains and lack of planning creates victims in Santa Catarina," he comments: "Initially, authorities blamed climate change and excessive rain. But according to experts, the main causes of the chaos are known and recurring: disorderly occupation of the hills and slopes, destruction of native vegetation, lack of mapping of risk areas and the absence of studies of soil conditions prior to construction" (Veríssimo 2008). His emphasis on these other factors further suggests that dominant expert framings in Brazil deemphasize the role of climate change in this and other disasters, and shows great care to focus blame on local-level disaster management and prevention, not on climate change.

\subsection{Serrana 2011}

The onset of the 2011 Serrana landside disaster on 11 November followed a rainfall of $573.6 \mathrm{~mm}$, nearly half it falling in a 24 -h period $(61.8 \mathrm{~mm}$ fell within a single hour). A total of 905 people died and another 300 were never found. The disaster affected approximately 300,000 people and caused vast damage to infrastructure, causing over USD2 billion in material damages (Banco Mundial 2012b).

Deemphasis on the possible role of climate change in this extreme event is already evident in the small number of articles in Folha de São Paulo which mention this major national disaster in relation to climate change. Of a total of 280 climate change-mentioning articles 
during the 12-month period following its onset, only six mentioned the disaster, and only four had content relevant to our analysis of discursive (de)linking to climate change.

Featuring US-based non-Brazilians, two of the four articles emphasized the role of climate in the Serrana disaster. One of them conveyed former US Vice President Al Gore's message to Brazilians in the wake of the disaster. The title- "Inundations are provoked by global warming, says Al Gore" (Fusco 2011) - reflected Gore's singular and emphatic attribution of the disaster to climate change. His message was similar to that of US-based atmospheric scientist Kevin Trenberth, the focus of the second article, whose title communicated his key message: "Global warming makes soft rain turn torrential" (Mioto 2011).

Their framings starkly contrasted those presented by Brazilians in the other two articles. As in the case of the Santa Catarina disaster coverage discussed above, not a single article about the Serrana tragedy featured Brazilian scientists or climate advocates linking climate change to the disaster. Written by Marina Silva, one of the two articles (Silva 2012) attributed the Serrana disaster mainly to lack of environmental foresight and precaution ("imprevidência"). Exhibiting the same emphasis as her 2008 Santa Catarina-focused article above, she mentioned climate change only to say that government development plans contradict official climate policy by increasing, rather than reducing, deforestation. This lack of connection between climate policy and important decisions affecting vulnerability to disasters is relevant to our analysis and treated in Section 4.

The second article's headline was especially revealing: "For specialists, Warming did not Cause Tragedy" (Folha de São Folha De São 2011). Covering a debate among Brazilian experts about rain-induced catastrophes, in general, and the Serrana disaster, in particular, the article explicitly conveyed the consensus conclusion of Brazilian professors and researchers from top national research universities, including IPCC-involved climate scientists. "It is not possible to say that this is a result of climate change, because events like these have been occurring for decades," a leading atmospheric scientist is quoted saying. With colleagues, he emphasized the need for disaster prevention policies, including timely disaster warnings, alarms, and helping the poor secure housing in less disaster-prone areas. Calling for improved systems, laws, and law enforcement to enhance resilience, participating experts characterized the country's mapping and systems of disaster warnings as "light years behind."

The contrast between the conclusions drawn by the specialists based in Brazil and those in the USA exemplified by these articles suggests a decidedly geographical structuring of framing choices. Moreover, the fact that even Brazil's environmental leaders and scientific experts delink the extreme events from climate change suggests the role of "blame games" (Hood 2010; Weaver 1986) - strategies to attribute blame - rather than ignorance or environmental skepticism. As apparent in the content analyses above (Sections 3.1 and 3.2) and further below (Section 4), these national scientific and environmental leaders emphasize other problems because pressure for action focused on them potentially could yield higher benefits, in the form of reduced deforestation and improved resilience to weather-related disasters, whether related to climate change or not.

\subsection{Analysis of major debates: dominance of government actors who stress northern responsibility and Brazil's emission reduction achievements}

Framings are always shaped by broader fields of contestation and meaning, including perceived opportunities to achieve social or political purposes (Carpenter 2014; Koopmans 2004; Snow 2008). 
To understand the broader context of the disaster framing tendencies that we found in Folha de São Paulo's coverage, we analyzed dominant discourses and policy opportunities when they occurred, broadening our analysis to also include the two other newspapers (minus Valor Economico in the 2011 analysis).

\subsubsection{7-2008}

Applying our verb-centered search in the 3550 climate change-mentioning articles in the three newspapers in 2007-2008 (see Section 2.2) yielded 435 articles with debate statements, and 498 debate statements. Of these 498 statements, more than three-fourths (391 statements, i.e., $78 \%$ ) fell into three overarching topics, mentioned 152, 127, and 112 times, respectively: (1) high and lower income countries' differential responsibility for emission reductions; (2) the impacts and benefits of biofuels; and (3) the need to address deforestation (see Table 1).

Mentioned 50 times, differential responsibility was the highest overall topic of debate this period, also ranking first among the 22 statements (see Table 1). In Section 4, we indicate the importance of this finding for understanding of the Brazilian framing choices apparent in our Discursive Linking Analysis, considering also the clear indications in our Debate Analysis that Brazil's government both is a dominant national actor and emphatically stresses the principle of differential (i.e., global North) responsibility for mitigating climate change. This stance was promoted by Brazilian diplomats as leaders of the G77 with China in UNFCCC negotiations (Viola and Franchini 2017).

Figure 1 shows the relative dominance of various actors in the climate change media debates presented in Table 1. Forty-three percent of all statements during this 2007-2008 were by the federal government, meaning that it strongly dominates national debates. Seventy-eight percent of its statements were expressed by just three actors: the President of the Republic (29\%), the Ministry of Foreign Relations (29\%), and the Environment Ministry (20\%). Other government sub-entities trail far behind with five or less percent of the federal government total. Professionalized non-governmental organizations provide $15 \%$ of the debate statements, social movement actors only $1 \%$. Business representatives and state governments each expressed just $3 \%$ of all statements.

The debate data reflected strong national agreement that Brazil should reduce its deforestation to achieve emission reductions (93\% agreed versus $7 \%$ who disagreed). The issue of differential responsibility was one of the top three most frequent statements, and it was subject to a modest consensus ( $70 \%$ versus $30 \%$ of the statements agreed with the need of differential responsibility). In mentioning this position more than ten times, diplomats from the Ministry of Foreign Relations and the President of the Republic appear as its primary proponents. In the 2007-2008 statements, Brazil's Ministry of Foreign Relations diplomats were also unique in expressing ten or more times a perceived conflict between development and climate change mitigation. The Federal President and representatives of the Ministry of Foreign Relations and the Environment Ministry all made statements ten or more times to the effect that the (then) current Brazilian actions to reduce climate change were strong and sufficient. Expressing its ambivalent position between the government and civil society, the Environment Ministry also stressed, with scientists in both governmental and non-governmental research institutions, that the government needs to do more to reduce national emissions from deforestation.

Whereas the government-stressed position of differential responsibility was subject to modest consensus (see above), 65\% of the featured actors expressed statements in disagreement with the government-promoted position that "Current Brazilian actions to reduce climate 
Table 1 Major national debates: most frequent frames of debate in climate change-mentioning articles in three Brazilian newspapers (Folha de São Paulo, Estado de São Paulo, and Valor Econômico) during 2007-2008. The right-hand column indicates the number of times a particular topic was raised, regardless of whether actors agreed or disagreed with the statement. Of the 498 debate statements found, 391 (78\%) can be categorized into three overarching themes, which are coded in this table with a color scheme

\begin{tabular}{|c|c|c|}
\hline & DEBATE STATEMENT & $\begin{array}{l}\text { Number of } \\
\text { times } \\
\text { mentioned, } \\
\text { both for and } \\
\text { against the } \\
\text { statement } \\
\text { framing }\end{array}$ \\
\hline 1 & $\begin{array}{l}\text { Developed and developing countries should have different responsibilities in the } \\
\text { climate regime }\end{array}$ & 50 \\
\hline 2 & Ethanol is an effective and desirable solution for climate change and beneficial to Brazil & 41 \\
\hline 3 & $\begin{array}{l}\text { Avoided deforestation should be achieved through a financial compensatory } \\
\text { mechanism }\end{array}$ & 41 \\
\hline 4 & Food production is at risk from climate change-related impacts and policies (biofuels) & 41 \\
\hline 5 & Nuclear energy is a viable and desirable alternative to fossil fuels & 37 \\
\hline 6 & Biofuels are an effective and desirable solution for the climate problem & 32 \\
\hline 7 & Current Brazilian actions to reduce climate change are strong and sufficient & 32 \\
\hline 8 & Brazil should reduce its deforestation to achieve emissions reduction & 26 \\
\hline 9 & The national climate plan is adequate & 24 \\
\hline 10 & There is opposition between development and climate change mitigation & 21 \\
\hline 11 & $\begin{array}{l}\text { Brazil and others developing countries can assume climate commitments } \\
\text { independently of developed countries }\end{array}$ & 20 \\
\hline
\end{tabular}

change are strong and sufficient." This disagreement indicates a declared pressure on Brazil's political leaders to adopt binding commitments to emission targets. Even so, Greenpeace — an internationally headquartered environmental group which has offices in Brazil — was alone in 
Table 1 (continued)

\begin{tabular}{|c|c|c|}
\hline 12 & Climate change is an economic and technological opportunity & 17 \\
\hline 13 & Brazil should have emission reduction commitments & 15 \\
\hline 14 & $\begin{array}{l}\text { Developed countries must not be allowed to interfere with deforestation reduction } \\
\text { strategies }\end{array}$ & 14 \\
\hline 15 & Ethanol production can bring deforestation and social impacts & 13 \\
\hline 16 & Lifestyle and consumption changes are needed to address climate change & 11 \\
\hline 17 & Adoption of REDD in UNFCC was desirable & 11 \\
\hline 18 & Renewable energy production helps solve the climate change problem (in Brazil) & 11 \\
\hline 19 & The financial crisis can reduce measures to address climate change & 11 \\
\hline 20 & Deforestation of the Amazon is related to climate change & 10 \\
\hline 21 & Science has decidedly identified climate change as human caused & 10 \\
\hline 22 & The forest agenda must be included in the international climate negotiation & 10 \\
\hline
\end{tabular}

\begin{tabular}{|l|l|}
\hline Light gray: North-South responsibility & Total times mentioned: $\mathbf{1 5 2}$ \\
\hline Dark gray: Impacts and benefits of biofuels & Total times mentioned: $\mathbf{1 2 7}$ \\
\hline Black: Deforestation & Total times mentioned: $\mathbf{1 1 2}$ \\
\hline White: Other topics than the above three & Times mentioned: $\mathbf{1 0 7}$ \\
\hline
\end{tabular}

presenting the argument more than ten times that "Brazil and other developing countries can adopt climate commitments independently of developed countries" (debate statement number 11 in Table 1). Compensating for the otherwise total absence of national backing of its position statement, Greenpeace presented it emphatically—a total of twenty times.

\subsubsection{1}

Resonating with the abovementioned environmental leaders' discussions of deforestation and, specifically, of lacking enforcement of related national laws (e.g., the Forest Code) as contributor to both disasters (see Sections 3.1 and 3.2), forest protection was the most frequent topic in 2011. Year 2011 was the year of decisive debate and voting on the revisions to the national Forest Code, revisions criticized by environmental leaders, but which were coveted by 


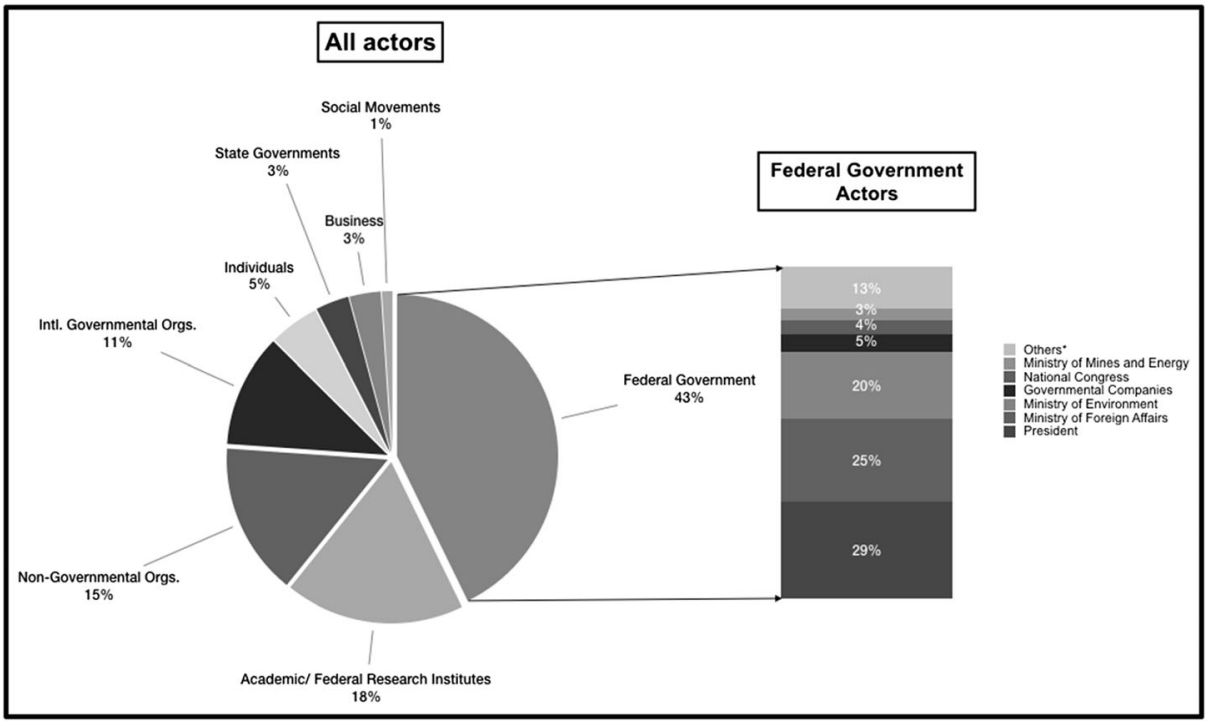

Fig. 1 Sources of debate statements. This figure shows in percentages the relative representation of organizational actors who made debate statements in the three Brazilian newspapers during 2007 and 2008. The bar on the right shows, in percentages, the relative representation of sub-entities comprising the federal government, which presented $43 \%$ of all debate statements. "Others" refers to sub-entities which each provided less than $5 \%$ of the featured government statements. These were the ministries of agriculture and livestock, science and technology, development, and industry and trade, as well as the environmental enforcement agency, IBAMA

the powerful agricultural lobby and aligned politicians, who forcefully pressed for them for years.

Extreme events ranked as the 7th most frequently mentioned topic, whereas they were not anywhere among the top 22 topics in the 2007-2008 debates. In line with the framings of both disasters revealed by our discursive linking analyses above, however, the prevalent cause of the extreme events discussed in the 2011 coverage was not climate change but poor forest protection and lacking disaster prevention.

\section{Discussion}

US-based thought leaders emphasize the climate role in extreme events to "spur more immediate action" (Mcnutt 2019, p. 411). Understanding extreme events as opportunities to call attention to climate change, they approach delinking as a problem to be addressed and as a function of insufficiencies, e.g., at the levels of public understanding or journalistic capacity. Part of a broader emphasis on extreme events as opportunities to shape public opinion and policies in favor of climate action (see, for example, Albright and Crow 2019; Davidson et al. 2019; Mann et al. 2017), this understanding drives their policy recommendations in direction of public education campaigns.

Our analysis suggests that there are geographical limits to the validity of this understanding and of associated assumptions and framing recommendations. It shows the importance of contextual understanding to properly evaluate and guide framing choices bearing on disasters and climate change; it cannot be assumed a priori that knowledge, care, or conviction with 
regard to the reality of climate change warrants emphasis on its role in disasters, even where attribution studies might find such a role.

Moreover, we suggest that recognition of the geographical limits to the validity of this understanding ought to guide science and funding agendas, helping define whether and where more precise attribution of climate change should be a top science priority. It should also help ensure that communication strategies are fit to specificities of contexts, considering not only particularities of national climate change politics but also whether communications allow proper space and consideration to the multiplicity of problems vying for attention and policy improvement. Stressing climate change does not always serve climate action, and it does not and should not always trump all other concerns.

Rather than deficits at the level of understanding and care, our findings indicate that astute understanding of policy opportunities and trade-offs in the areas of climate change, forest conservation, and disaster prevention underpin Brazilian actors' tendency to actively play down the role of climate change and, sometimes, even actively and emphatically disassociate it from extreme events. This was apparent in our Discursive Linking Analysis and is further reinforced by our discussion below of a number of factors underpinning the national tendency to deemphasize the climate role in the two disasters: a relative absence of climate skepticism nationally, low probability that the climate frame would stimulate additional policy action, dismal national performance in the area of disaster prevention, and felt urgency to counter lobby groups' increasing pressure to weaken laws protecting Brazil's flora and fauna. According to our data and analyses here, disaster prevention and nature conservation-Brazil's highest ranked environmental issue of concern-were not obviously served by framing extreme events as expressions of climate change.

\subsection{High public concern and low levels of climate skepticism}

American scientific thought leaders' climate-stressing messages about disasters are adapted to a context very different from that of Brazil, where the population already expresses exceptionally high levels of concern about climate change (Lewis et al. 2019). Ignorance and skepticism about the theory and reality of human-induced climate change have little apparent hold. In line with this, the 2007-2008 and 2011 major debate statements revealed an important absence: none of them centers on confirming or contesting whether or not climate change is happening. Similarly, our discursive linking analyses found no skeptical views expressed about the theory of climate change. It revealed that Brazilian scientific and political environmental leaders spearheaded the push-back against interpretations of the two tragic disasters as caused by climate change. These actors are not uninformed with regard to climate change, nor indifferent, nor unconvinced. Nor are Latin Americans as a whole (Carle 2015). Confirming a tendency in surveys spanning decades (Leiserowitz 2007; Lorenzoni and Pidgeon 2006), a 2015 Pew Research Center survey found $75 \%$ of Brazilians to express high concern about climate change (Carle 2015), and a 2019 international comparison showed them to be the most climate concerned population in the world (Lewis et al. 2019). While there are important, ideological limitations to Brazilian newspapers' climate coverage (Lahsen 2017), US-style climate skepticism is not prevalent in it (Dayrell and Urry 2015; Painter and Ashe 2012). Current studies find that skepticism about the theory and adverse impacts of human-induced climate change is mostly — or most strongly — a phenomenon in the global North and, primarily, in the USA, from where it diffuses only in a limited manner (Jacques et al. 2008; Painter 2011; Painter and Ashe 2012). 
The findings of this study lead us to suggest that where climate skepticism is low, discursive space opens up for framing disasters such that they lead attention to other problems and solutions. Calling attention to climate change as cause is relatively less necessary in a context of generalized acceptance of its reality and high levels of worry about it.

\subsection{Governmental leaders' dominance in national discourses limit policy opportunities related to climate change}

The findings of this study indicate that Brazilian policy and discursive contexts imposed formidable obstacles to policy development on climate change. Importantly, past policy achievements and countervailing positions of powerful national political leaders offer relatively limited opportunity for strengthening national climate policy. Our Major Debate Analysis revealed the strong dominance of federal governmental actors in print media debates around the disasters: they offered $43 \%$ of all statements presented in the articles analyzed. Over half of this subset of government statements were made by the President of the Republic and the Ministry of Foreign Affairs, and they stressed emphatically that developed and developing countries should have differential responsibilities in the climate mitigation. Together with Environment Ministry representatives (with whom they contributed $74 \%$ of all government statements), they also stressed that current Brazilian actions to reduce climate change were strong and sufficient during the period in focus.

The emphasis on Northern responsibility was subject to a modest consensus among the statements analyzed. By contrast, the government-promoted statement that current Brazilian actions to reduce climate change were strong and sufficient was contested by $65 \%$ of all statements on the topic, reflecting interpretations to the contrary. Nevertheless, the strength of government actors in national media coverage of climate change, and their emphatic stress of these positions present a powerful constraint to further development of climate change mitigation policies. Our Major Debate Analysis (Section 3.3) indicated considerable support for the principle of developed countries' primary responsibility, understanding of national climate action as already considerable, and a government perception of conflict between national development priorities and additional emission reductions, as especially expressed by the powerful Ministry of Foreign Affairs.

Objectively, Brazil could do more to reduce its greenhouse emissions. Its emissions from agriculture, energy, industrial activity, and waste were and remain high (de Azevedo 2016), and emissions from deforestation are "irrationally" high compared with the country's associated economic output (Viola and Franchini 2017). Already in the early 2010s, leading analysts expressed doubt that the country would reach even the lower range of its official national emission reduction goal by 2020 due to insufficient federal prioritization and resource allocation (Pagliosa et al. 2012).

On the other hand, emissions from energy use in Brazil remain exceptionally low compared with those of most countries because of the large share of renewable sources (Ministério da Ciência e Tecnologia 2010). Moreover, Brazil has made great achievements in climate policy and emission reductions from deforestation. Between 2005 and 2011, Brazil achieved a 30\% reduction in its carbon emissions by lowering the rate of deforestation - an internationally unequaled reduction at a time when the globally national average was a $9 \%$ emissions increase compared with 1990 levels (Economist 2010). This reduced its share of global emissions from 6 to approximately $2.5 \%$ (de Azevedo 2012). In addition, Brazil went from having no climate policies in 2000 to significant voluntary commitment to emission reductions in 2009 (at least 
$36.1 \%$ by 2020 relative to a projected business-as-usual scenario). Furthermore, it enshrined this international commitment into a national climate law in 2009 and increased its mitigation commitment further in 2015 , becoming the only developing country with an absolute mitigation target for 2025 (Aamodt and Stensdal 2017).

Brazil's emission achievements and their political use are apparent in the governmentpromoted major debate statements (statements 7 and 9). The positions expressed and promoted by the government actors confirm other analysts' assertions (Viola and Franchini 2017) that the country's emission achievements have enabled Brazil's government to promote an idealized understanding of Brazil as an environmental superpower that has exceeded its responsibilities as a developing country. This discourse gained traction, also internationally (Howard 2014; Nepstad et al. 2014; Patterson 2016; Richards et al. 2017), starting in the late 2000s when Brazil was able to reduce the worst excesses of deforestation in the Amazon.

\subsection{Dismal disaster prevention and its decoupling from climate policy}

Whereas Brazil could boast of climate policy achievements during the timeframe in focus, national disaster preparedness was marked by profound failure, as also recognized by the government itself under the United Nations Hyogo Framework for Action. Just months before the Serrana disaster, Brazil submitted an obligatory report to the UN with an inventory of national actions and preparedness in face of calamities due to flooding, drought, earthquakes, and similar extreme events, admitting nearly total unpreparedness (Chade 2011). The chronic nature of this general lack of preparedness was captured by Brazil's former Environment Minister, Green party representative, and Secretary of Environment in the Rio de Janeiro State Government, Carlos Minc: "In Brazil, there is no culture of prevention. In countries with cyclones and earthquakes, there are frequent simulations and training sessions, even for children. Here, until very recently, sirens and risk mapping were inexistent. Environmental (and not only environmental) impunity is the rule ..." (Minc 2015).

Relatively little institutional and financial support is to be found nationally and internationally to enhance climate adaptation and resilience. Largely delegated by the UNFCCC to national decision making, adaptation is subject to inadequate traditional international development funding (Council of Foreign Relations 2013). Nationally, official climate policies do not necessarily translate into climate vulnerability reduction and adaptation, due to a disconnect between official climate policy and actual decision-making at the level of forest - and more generally land - management, as was emphatically pointed out by Marina Silva and other environmental leaders discussed in The Discursive Linking Analysis.

Emphasizing the climate role in extreme events might encourage disaster prevention in some contexts, but this was not the case in Brazil during the periods we have examined. This helps explain why Brazilian environmental science and political leaders would forego the climate frame and instead center responsibility on actors or decisions which reduced vulnerability to extreme events in general. Tellingly, the media coverage portrayed local government officials' initial attribution of the Santa Catarina disaster as a convenient but unconvincing means to escape their responsibility for the deep and chronic lack of disaster prevention, and national experts highlighted the role of poor monitoring and alarm systems, poverty, vegetation loss, and disorderly occupation of hills and slopes. As such, the Brazilian framing choices emphasizing more direct human drivers (compared with an indirect human role in the form of climate change) reflect well-informed blame gaming. Besides their important moral inflections, the choices to stress poor environmental decision-making, lacking disaster preparedness, 
and socio-economic inequality rather than climate change are politically astute considering the divergent national policy opportunities in the areas of climate change and disaster prevention.

\subsection{Competing concerns}

US scientific thought leaders' recommendations to emphasize the climate link to extreme events assume that doing so is strategic for environmental policy, and they implicitly posit climate change as serving - or trumping - all legitimate concerns. Our analysis of Brazil does not support this assumption.

Under the combination of circumstances that we have outlined above, pressing for national vulnerability reduction through a climate framing was a less obvious means of obtaining such an outcome, compared with a direct attack on faulty national disaster preparedness, including relevant forest and land management. In a sense, then, the framing away from the climate role in the tragic national extreme events might, at least in some instances, reflect a strategy to reduce national vulnerability to extreme events and, as such, also to climate change, to the extent that it expresses itself in the intensification of such events.

On the other hand, climate change is not the only concern in societies vulnerable to extreme events, and disasters can offer windows of opportunity for changes beyond climate, as they touch interacting domains, including social, economic, environmental, and legal systems (Birkmann et al. 2010, p. 650). As citizens of a country marked by exceptionally high levels of both socio-economic inequality and biological diversity, including two biodiversity hotspots (the Atlantic Forest and the Cerrado) and the larger part of the Amazon forest (IPBES 2018), Brazilians have more than climate change to care about, forcing additional strategic choices about what problems to emphasize when framing major, tragic extreme events. Deforestation in Brazil's biodiversity-rich biomes is causing deep losses of ecosystem services and biodiversity that undermine nothing less than water, food, energy, and climate security in Brazil and beyond (Cowie 2018; Lahsen et al. 2016).

While Brazilians care deeply about climate change, surveys show that they attach great national pride and value to their abundant and beautiful natural environment (Brasil 2012). Indeed, they persistently rank deforestation and not climate change as the most important environmental problem (Crespo 2002; Crespo and Leitao 1993), and not only for Brazil: a 2012 survey found that only $10 \%$ of Brazilians listed climate change as the world's most important environmental problem, against $64 \%$ who listed deforestation first (Brasil 2012).

This is highly pertinent to our analysis here since, during the years leading up to 2012 , circumstances compelled environmental leaders to mobilize to protect national forest laws against lobby groups' forceful — and, in 2012, eventually successful-pressures to weaken them. The proposed revisions to the Forest Code were intensely debated, as Brazilians rightly (Azevedo et al. 2017) worried that the revisions would intensify forest loss, as well as risk of flooding and landslides in cases of intense rainfall. Both our discursive linking and our major debate analyses showed Brazilian actors contesting insufficient enforcement of the Forest Code and pressures to weaken it, which would increase deforestation. Given that Brazilian decision-making bears so importantly on planetary biodiversity loss and conservation, and considering also other relevant circumstances discussed above, the Brazilian tendency to use extreme events to draw attention to this problem and other highly pertinent national social and policy issues can seem strategic and wise. 


\subsection{Science communication and counter-factual reflections}

Disasters are generally multi-causal, including climate patterns and human decisions affecting vulnerability and resource use (Ribot 2009). Theoretically, that reality can be communicated. However, neither American nor Brazilian framings reviewed here generally did so. Instead, this study reveals that public actors are inclined to either highlight or else downplay, if not dismiss, the role of climate change in contributing to disasters. Popular communication tends towards simplification, as scientific nuances and qualifications can undermine clarity, sow confusion among publics, and fail to promote desired action paths (Hassol, et al. 2018).

The science of attributing specific extreme events to climate change is uncertain, and recent studies find that direct human drivers (e.g., decision-making affecting resource use) are more important than climate change in recent droughts in Brazil, for example (Otto et al. 2015). Current attribution science thus offers Brazil's scientific and environmental leaders flexibility to frame extreme events in ways that serve their particular concerns and policy context. What would it have meant for Brazilians' environment, politics, and policies if the science had come to be considered certain and unambiguous as to the role of climate change in the events in focus - or if it comes to be considered thus in the context of future extreme events?

Despite common beliefs and scientific ideals to the contrary, science does not determine social interpretations, and scientific claims bear the imprint of societal forces (Jasanoff 2004); they are inflected with diversity of meanings and morality, not least when they are communicated to society (Candall, 2010). Nevertheless, understandings accepted as scientific facts do weigh strongly, especially among scientific and political environmental leaders; they restrict the legitimacy of some interpretations relative to others, especially in science-laden environmental - as opposed to anti-environmental — subcommunities and networks (Lahsen 1999; Layrargues 2018). In the counterfactual scenario considered immediately above, such enhanced certainty or authoritative claims would reduce the interpretive flexibility available to Brazilian scientific and environmental leaders to focus blame on more direct, urgent, and relevant social and political causes, and to thus exert pressure for more responsible decisionmaking where it might be more deserved and beneficial - in the area of forest protection, for example, and enhanced societal resilience.

\section{Conclusion}

Disasters raise discussions of human blame and responsibility and can provide lessons for future improvements, but the strategic value of attributing extreme events to climate change depends on the nature of existing policies and on opportunities for new ones-factors subject to national variation. As such, our study suggests that more attention should be paid to understanding context-specific politics of disaster framings, as distinct from the science of attributing extreme events to climate change. Best practice recommendations for disaster framing should be premised on understanding of particularities of national policy and politics in different parts of the world — not least since mobilizations of attribution science to stimulate "climate action" might, in some contexts, have the paradoxical effect of lessening pressures on decision-makers responsible for local-level resilience measures.

We found a strong tendency in Brazilian newspapers to deemphasize the role of climate change in the two extreme events in focus. Sometimes, their deemphasis on the climate role in such events might, ironically, offer more promising ways of prompting climate-relevant action. 
Contrary to dominant deficit-finding assumptions, we suggest that Brazilians' framing tendency away from climate change reflects intelligent strategizing integrating both wellinformed policy understanding and morally inflected "blame games." Brazilians tend to focus blame on more immediate causes of disasters, and on other important policy areas where decision-making is lacking - areas where national-level decision-making also is urgent and, considering the national policy and political particularities, sometimes arguably more in need of political pressure and action.

Future research could produce a longitudinal set of studies that scrutinize public discourses around climate mitigation, adaptation, disaster management, and resilience. They might examine whether different types of disasters (droughts versus floodings and landslides, for example) generate different framing tendencies, and whether different methods and a focus on different types of media, including social media, reveal different patterns from elite newspapers of the sort analyzed here. Research might also explore whether increases in Brazil's emissions since 2011 (INPE (Instituto Nacional de Pesquisas Espaciais) 2019) and, possibly, in climate skepticism in Brazil, especially since the election of Jaír Bolsonaro in late 2018 (VOA News 2019), bring new framing tendencies around extreme events in Brazil. Under the Bolsonaro government, climate skeptics occupy prominent minister posts, federal funds to implement national climate policy have been cut by $95 \%$, and forest fires have spiked, greatly increasing national emissions (Climate Action Tracker 2019; Rodrigues 2019). These factors could encourage framings of extreme events that stress the reality of climate change.

Changes brought about by the Paris Agreement could also reshape framing politics in Brazil and beyond. In particular, the softened distinction between responsibilities between the Global North versus South might weaken discursive emphasis on differentiated responsibilities in national attribution politics in former non-Annex 1 countries. On the other hand, the specification of common but differentiated responsibilities remains relevant in international politics, as it is enshrined in the broader United Nations Framework on Climate Change (Maljean-Dubois 2016), and Brazil's political leaders continue to consider change on this point "tantamount to the annihilation of the UNFCCC" and counter to principles of justice (Rajão and Duarte 2018: p. 7).

The combination of factors which encourage delinking of extreme events from climate change in Brazil might be unique, but some of these are shared by other countries of the former G-77 block of less developed countries. That includes "rigid" insistence on common but differentiated responsibilities under the UNFCCC (Yeo and Evans 2015), tendencies towards low levels of climate skepticism (Painter and Ashe 2012), and high levels of public worry about climate change (Carle 2015; Lewis et al. 2019). Emphasizing the role of climate change in extreme events might still serve to push for national climate policy in countries of the global South, but the need to do so may sometimes appear relatively less urgent, especially considered against other urgent issues of concern and policy opportunities. Future work might explore whether policy-savvy strategizing and blame games in other lower income countries discourage linking extreme events from climate change, as we have shown to be the case in Brazil, tracing the particular dynamics and effects in countries marked by different circumstances.

A final point bears emphasis: sometimes alternative framings can be more effective means of achieving climate relevant policy. For example, in the US context, where polarized partisanship and cultural politics structuring interpretations of climate science and climate policy needs can make climate mitigation and adaptation more achievable under the heading of cost-reducing energy efficiency (Prins et al. 2010). Similarly, but for other reasons, Brazilians do not always opt for the climate frame to achieve climate relevant policy, such as forest 
protection and enhanced societal resilience to extreme events. Counter-intuitively, stressing climate change to achieve climate-relevant policy is not always the most effective means of achieving it.

Funding information The research benefited from support from the US National Science Foundation (grant no. $1544589)$ and from the Brazilian Counsel of Technological and Scientific Development (CNPq) for the project "Science, Technology and Policy Studies" (CNPq 483099/2009-0) under the Brazilian National Institute for Science and Technology — Climate Change (INCT-MC).

Open Access This article is licensed under a Creative Commons Attribution 4.0 International License, which permits use, sharing, adaptation, distribution and reproduction in any medium or format, as long as you give appropriate credit to the original author(s) and the source, provide a link to the Creative Commons licence, and indicate if changes were made. The images or other third party material in this article are included in the article's Creative Commons licence, unless indicated otherwise in a credit line to the material. If material is not included in the article's Creative Commons licence and your intended use is not permitted by statutory regulation or exceeds the permitted use, you will need to obtain permission directly from the copyright holder. To view a copy of this licence, visit http://creativecommons.org/licenses/by/4.0/.

\section{References}

Aamodt S, Stensdal I (2017) Seizing policy windows: policy influence of climate advocacy coalitions in Brazil, China, and India, 2000-2015. Glob Environ Chang 46:114-125

Albright EA, Crow D (2019) Beliefs about climate change in the aftermath of extreme flooding. Clim Chang $155: 1-17$

Angelo C (2009) Caos Climático Tende A Piorar No Futuro. Folha De Sao Paulo 8 February

Azevedo AA, Rajão R, Costa MA, Stabile MCC, Macedo MN, dos Reis TNP, Alencar A, Soares-Filho BS, Pacheco R (2017) Limits of Brazil's Forest Code as a means to end illegal deforestation. Pnas 114:76537658

Azevedo T R de (2012) Estimativas De Emissões De Gases De Efeito Estufa No Brasil 1990-2011. Versão Preliminar, Novembro. https://Docs.Google.Com/File/D/0b_Utbmo5lpxhrm5yvedithy3de0/Edit?Pli=1

Azevedo T R de (2016) Análise Das Emissões de GEE Brasil (1970-2014) E Suas Implicações Para Políticas Públicas E A Contribuição Brasileira Para O Acordo De Paris. Seeg And Observatório Do Clima. http://Seeg.Eco.Br/Wp-Content/Uploads/2016/09/Wip-16-09-02-Relatoriosseeg-Sintese-.Pdf

Mundial Banco (2012a) Avaliação De Perdas E Danos: Inundações Bruscas Em Santa Catarina-Novembro De 2008. Relatório Elaborado Pelo Banco Mundial Com Apoio Do Governo Do Estado De Santa Catarina. Brasília: Banco Mundial

Mundial Banco (2012b) Avaliação De Perdas E Danos: Inundações E Deslizamentos Na Região Serrana Do Rio De Janeiro-Janeiro De 2011. Relatório Elaborado Pelo Banco Mundial Com Apoio Do Governo Do Estado Do Rio De Janeiro. Brasília

Bandeira A, Nunes P, Lima M (2016) Environmental risk management in municipalities of the metropolitan area of Cariri, Ceará, Brazil. Environ Plann C 19:81-100

Barkemeyer R, Figge F, Hoepner A, Holt D, Kraak Jm YP-S (2017) Media coverage of climate change: an international comparison. Environment And Planning C: Politics And Space 35:1029-1054

Barros M (2008) Urbanista Defende Parâmetros Rígidos. Folha De Sao Paulo 29 November

Birkmann J, Buckle P, Jaeger J, Pelling M, Setiadi N, Garschagen M, Fernando N, Kropp J (2010) Extreme events and disasters: a window of opportunity for change? Analysis of organizational, institutional and political changes, formal and informal responses after mega-disasters. Nat Hazards 55:637-655

Boykoff MT (2011) Who speaks for the climate?: making sense of media reporting on climate change. Cambridge University Press, Cambridge

Brasil (2012) Ministério Do Meio Ambiente. Secretaria De Articulação Institucional E Cidadania Ambiental. O Que O Brasileiro Pensa Do Meio Ambiente E Do Consumo Sustentável: Pesquisa Nacional De Opinião: Principais Resultados / Ministério Do Meio Ambiente, Secretaria De Articulação Institucional E Cidadania Ambiental. - Rio De Janeiro: Overview 
Callison C (2010) More information is not the problem : spinning climate change, vernaculars, and emergent forms of life. Massachusetts Institute Of Technology Program In Science, Technology And Society, Cambridge

Carle J (2015) Climate change seen as top global threat. Pew Research Center: Public Attitudes \& Trends, Washington D.C http:/www.Pewglobal.Org/2015/07/14/Climate-Change-Seen-As-Top-Global-Threat/

Carpenter C (2014) "Lost" causes: agenda vetting in global issue networks and the shaping of human security. Cornell University Press

Chade J (2011) Governo Brasileiro Admite À Onu Despreparo Em Tragédias. Estado De São Paulo http://Brasil. Estadao.Com.Br/Noticias/Geral,Governo-Brasileiro-Admite-A-Onu-Despreparo-Em-Tragedias, 666689

Climate Action Tracker (2019) Climate crisis demands more government action as emissions rise

Council Of Foreign Relations (2013) The global climate change regime: report by International Institutions and Global Governance Program, Global Governance Monitor. https://www.Cfr.Org/Report/Global-ClimateChange-Regime

Cowie S (2018) Brazil: experts warn of Bolsonaro threat to the Amazon. Deutsche Welle 29 October, https://www.Dw.Com/En/Brazil-Experts-Warn-Of-Bolsonaro-Threat-To-The-Amazon/A-46068377

Crespo S (2002) O Que O Brasileiro Pensa Do Meio Ambiente E Do Desenvolvimento Sustentável. Brasília: Ministério Do Meio Ambiente

Crespo S, Leitao P (1993) O Que O Brasileiro Pensa Da Ecologia. Iser, Rio De Janeiro

Davidson DJ et al (2019) Missed opportunities: the absence of climate change in media coverage of forest fire events in Alberta. Clim Chang 153(1-2):165-179

Dayrell C, Urry J (2015) Mediating climate politics: the surprising case of Brazil. Eur J Soc Theory 18:257-273

Economist T (2010) The miracle of the Cerrado. Brazil has revolutionised its own farms. Can it do the same for others. The Economist. http://www.Economist.Com/Node/16886442/Print

Folha De São P (2011) Para Especialistas, Aquecimento Não Causou Tragédia. 1 March. https://www1.Folha. Uol.Com.Br/Fsp/Cotidian/Ff0103201109.htm

Fusco C (2011) Inundações São Provocadas Pelo Aquecimento Global, Diz Al Gore. Folha De São Paulo, 24 October

Gabeira F (2008a) Chovendo No Molhado. Folha De São Paulo 19 December

Gabeira F (2008b) O Futuro Das Chuvas. Folha De São Paulo 28 November

Geraque E (2008) Fenômeno Extremo Vai Se Tornar Freqüente. Folha De Sao Paulo 29 November

Hassol SJ, Torok S, Lewis S, Luganda P (2016) (Un) natural disasters: communicating linkages between extreme events and climate change. Wmo Bulletin 65:https://Public. Wmo. Int/En/Resources/Bulletin/Unnatural-Disasters-Communicating-Linkages-Between-Extreme-EventsAnd-Climate

Hood C (2010) The blame game: spin, bureaucracy, and self-preservation in government. Princeton University Press, Princeton

Howard Bc (2014) Brazil leads world in reducing carbon emissions by slashing deforestation. Natl Geogr 5 June, https://www.Nationalgeographic.Com/News/2014/6/140605-Brazil-Deforestation-Carbon-EmissionsEnvironment/

INPE - Instituto Nacional De Pesquisas Espaciais (2019) Taxas Anuais De Desmatamento Na Amazônia Legal. http://Terrabrasilis.Dpi.Inpe.Br/En/Home-Page/. Accessed 7 Nov 2019

IPBES (2018). The IPBES regional assessment report on biodiversity and ecosystem services for the Americas. J. Rice, C. S. Seixas, M. E. Zaccagnini, M. Bedoya-Gaitán and N. Valderrama. Bonn, Germany, Secretariat of the Intergovernmental Science-Policy Platform on Biodiversity and Ecosystem Services

Jacques PJ, Dunlap RE, Freeman M (2008) The organization of denial: conservative think tanks and environmental scepticism. Environ Polit 17:349-385

Jasanoff S (2004) The idiom of co-production. States of knowledge: the co-production of science and social order. Taylor \& Francis, Inc., London, Pp. 1-12

Koopmans R (2004) Movements and media: selection processes and evolutionary dynamics in the public sphere. Theory Soc 33:367-391

Lahsen M (1999) The detection and attribution of conspiracies: the controversy over chapter 8. Paranoia within reason: a casebook on conspiracy as explanation. G.E. Marcus. Chicago, University of Chicago Press: 111136

Lahsen M (2017) Buffers against inconvenient knowledge: Brazilian newspaper representations of the climatemeat link. Desenvolvimento E Meio Ambiente 40

Lahsen M, Bustamante M, Dalla-Nora E (2016) Undervaluing and overexploiting the Brazilian Cerrado at Our Peril. Environ Sci Policy Sustain Dev 58:4-15

Layrargues, PP (2018) Quando os ecologistas incomodam: a desregulacao ambiental publica no Brasil sob o signo do Anti-ecologismo. RP3 - Revista Pesquisa em Politicas Publicas 12: 1-30 
Leiserowitz A (2007) International public opinion, perception, and understanding of global climate change. Human Dev Report 2008:1-40

Lewis G, Palm R, Feng B (2019) Cross-national variation in determinants of climate change concern. Environ Polit 28:793-821

Lorenzoni I, Pidgeon N (2006) Public views on climate change: European and USA perspectives. Clim Chang 77:73-95

Maljean-Dubois S (2016) The Paris Agreement: a new step in the gradual evolution of differential treatment in the climate regime? Reciel 25:151-160

Mann ME, Hassol SJ, Peterson TC (2017) Irma and Harvey should kill any doubt that climate change is real. Washingon Post 7 September, https://www.Washingtonpost.Com/News/Posteverything/Wp/2017 /09/07/Irma-And-Harvey-Should-Kill-Any-Doubt-That-Climate-Change-Is-Real/?Utm_Term=.0425 a7cb8ddc

Martins ES, Coelho CA, Haarsma R, Otto FE, King AD, Jan Van Oldenborgh G, Kew S, Philip S, Vasconcelos Júnior FC, Cullen H (2018) A multimethod attribution analysis of the prolonged Northeast Brazil hydrometeorological drought (2012-16). Bull Am Meteorol Soc 99:S65-S69

Mcnutt M (2019) Time's up, Co2. Science 365:411

Minc C (2015) Impunidade Ambiental. O Globo 29 November, https://Oglobo.Globo.Com/Opiniao/ImpunidadeAmbiental-18166621:15

Ministério Da Ciência E Tecnologia (2010) Segunda Comunicação Nacional Do Brasil À Convenção-Quadro Das Nações Unidas Sobre Mudança Do Clima. In: http://www.Mct.Gov.Br/Upd_Blob/0215/215070.pdf. Accessed Brasília, Df, Brasil

Mioto R (2011) Aquecimento Global Faz Garoa Virar Temporal. Folha De São Paulo

Nepstad D, Mcgrath D, Stickler C, Alencar A, Azevedo A, Swette B, Bezerra T, Digiano M, Shimada J, Rs DM (2014) Slowing Amazon deforestation through public policy and interventions in beef and soy supply chains. Science 344:1118-1123

Otto FE, Haustein K, Uhe P, Ca C, Ja A, Almeida W, King A, Coughlan De Perez E, Wada Y, Jan Van Oldenborgh G (2015) Factors other than climate change, main drivers of 2014/15 water shortage in Southeast Brazil. Bull Am Meteorol Soc 96:S35-S40

Pagliosa PR, Rovai AS, Fonseca AL (2012) Carbon mismanagement in Brazil. Nat Clim Chang 2:764

Painter J (2011) Poles apart. Reuters Institute For The Study Of Journalism Oxford

Painter J, Ashe T (2012) Cross-national comparison of the presence of climate scepticism in the print media in six countries, 2007-10. Environ Res Lett 7:044005

Pasquali, M. (2019). Brazil: digital subscriptions of selected newspapers 2018. 27 May, www.statistica.com. https:/www.statista.com/statistics/741223/leading-newspapers-in-brazil-by-digital-subscriptions/. Accessed 27 Nov 2019

Patterson B (2016) Brazil greenhouse gas emission spike blamed on deforestation. Sci Am https://www. Scientificamerican.Com/Article/Brazil-Greenhouse-Gas-Emission-Spike-Blamed-On-Deforestation/

Prins G, Galiana I, Green C, Grundmann R, Korhola A, Laird F, Nordhaus T, Pielke Jnr R, Rayner S, Sarewitz D (2010) The Hartwell paper: a new direction for climate policy after the crash of 2009

Rahmstorf S (2004) The climate sceptics. Weather Catastrophes And Climate Change:76-83

Rajão R, Duarte T (2018) Performing postcolonial identities at the United Nations' climate negotiations. Postcolonial Stud-uk 21:364-378

Ribot JC (2009) Vulnerability does not just come from the sky: framing grounded pro-poor cross-scale climate policy\% E Mearns, Robin. In Norton A (Ed.) Social dimensions of climate change: equity and vulnerability in a warming world. The World Bank, Washington, D.C.

Richards P, Arima E, Vanwey L, Cohn A, Bhattarai N (2017) Are Brazil's deforesters avoiding detection? Conserv Lett 10:470-476

Rodrigues S (2019) Governo Corta R\$ 187 Milhões Do Mma. Saiba Como O Corte Foi Dividido. O Eco https:/www.Oeco.Org.Br/Noticias/Governo-Corta-R-187-Milhoes-Do-Mma-Saiba-Como-O-Corte-FoiDividido/

Sarney J (2008) A Revolta Da Natureza. Folha De São Paulo 28 November

Shanahan M (2009) Time to adapt? Media coverage of climate change in nonindustrialised countries. Climate change and the media. London: Peter Lang:145-157

Silva M (2008) Mau Senso. Folha De Sao Paulo 8 December

Silva M (2012) Enxurrada De Descasos. Folha De Sao Paulo 6 January

Smeraldi R (2008) Lições De Santa Catarina: De Brasília A Poznan. Folha De São Paulo

Snow D (2008) Elaborating the discursive contexts of framing: discursive fields and spaces. Studies in symbolic interaction. Emerald Group Publishing Limited, pp. 3-28

Veríssimo J (2008) Chuvas E Falta De Planejamento Fazem Vítimas Em Sc. Folha De São Paulo, 30 November Viola E, Franchini M (2017) Brazil and climate change: beyond the Amazon. Routledge, New York 
Voa News (2019) Ap explains: Brazil's environmental changes under Bolsonaro. 15 May, https://www.Voanews. Com/Americas/Ap-Explains-Brazils-Environmental-Changes-Under-Bolsonaro

Weaver RK (1986) The politics of blame avoidance. J Public Policy 6:371-398

Yeo S, Evans S (2015) Explainer: why 'differentiation' is key to unlocking Paris climate deal. Carbon Brief 7 December, https:/www.Carbonbrief.Org/Explainer-Why-Differentiation-Is-Key-To-Unlocking-ParisClimate-Deal

Publisher's note Springer Nature remains neutral with regard to jurisdictional claims in published maps and institutional affiliations.

\section{Affiliations}

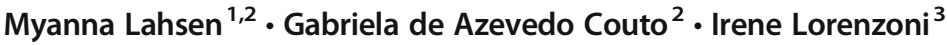

1 School of Social Sciences, Wageningen University, PO Box 8130, 6700 EW Wageningen, The Netherlands

2 Earth System Science Center, Instituto Nacional de Pesquisas Espaciais (INPE), Av. dos Astronautas, 1758 Jd. Granja, São José dos Campos, SP 12227-010, Brazil

3 School of Environmental Sciences, University of East Anglia, Norwich Research Park, Norwich NR4 7TJ, UK 